https://doi.org/10.24101/logos.2017.33

Gauta 20170119

\title{
SALOMĖJA JASTRUMSKYTE்
}

Lietuvos kultūros tyrimų institutas

Lithuanian Culture Research Institute

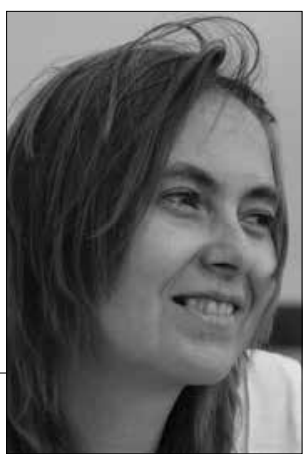

\section{KULTŪRŲ SĄVEIKOS TVERMĖ SOCIOKULTÜRINIUOSE VIRSMUOSE}

\author{
The Durability of Interaction of Cultures \\ in Socio-cultural Transformations
}

\begin{abstract}
SUMMARY
The article deals with problems of the current globalized world with constant multi-cultural interaction. The intercultural tangle of cultural interdependence, multiple cultural relations, influences, exchanges visible throughout thousands of years of civilization in history have intensified exponentially in recent decades. This tangle has become more sophisticated and complicated due to the complex of the present sociocultural transformations. However, no matter what form of cultural interaction occurs in local and global contexts, one's culture keeps one's stamina constant. It is one of the cornerstones of any culture, nation, or state derivative ideal.
\end{abstract}

\section{SANTRAUKA}

Straipsnis skirtas dabartiniame globalèjančiame pasaulyje vis aktualesnei ir itin svarbiai įvairių kultūrų sąveikos problemai, kuri autorès suvokiama kaip konstanta. Tarpkultūrinės sampynos, kultūrų tarpusavio priklausomybè, daugialypiai kultūriniai ryšiai, j̇takos, mainai regimi visoje tūkstančių metų civilizacijos istorijoje, tačiau pastaraisiais dešimtmečiais, plètojantis komunikacijoms, jie intensyvẻja nepaprastai sparčiai, dermès kinta ir darosi vis įmantresnès bei komplikuotesnès, šitaip atspindèdamos sudètingiausius dabarties sociokultūrinius virsmus. Tačiau kad ir kokius pavidalus igautų kultūrų sąveika lokaliuose ar globaliuose kontekstuose, ji išlaiko nekintamą savo tvermę, kuri yra vienas esminių bet kurios kultūros, tautos, valstybinio darinio sandų.

$\check{S}^{\mathrm{i}}$ iandien gyvename kaip niekada anksčiau sudètingame daugybès geopolitiniu ir civilizacinių prieštaravimu

pasaulyje, kuriame ryškèja naujos radikalios civilizacinès slinktys, įvairiose žemès rutulio dalyse įsiplieskiantys civilizaciniai

RAKTAŽODŽIAl: kultūru sąveika, daugiakultūriškumas, migracija, globalizacija, tapatumas, kultūra.

KEY WORDS: interaction of cultures, multi-culturalism, migration, globalization, identity, culture. 
konfliktai, kurie kaip svarbiausias iškelia skirtingų civilizacinių ir kultūros tradicijų harmoningos sąveikos problemas. Socialiniai konfliktai vienoje žemès rutulio dalyje dažniausiai sukelia tragiškas pasekmes ir kitose. Tai tik patvirtina pagrindinę šio straipsnio struktūrą styguojančią tezę apie postmodernioje epochoje stiprèjančią kultūru sąveikos tvermę sociokultūriniuose virsmuose.

Su globalizacijos procesais susiję pokyčiai apima įvairiausias dabartinès visuomenès, valstybès bei kultūros funkcionavimo sritis, mat intensyvejja tarpusavio ryšiai. Judrumo didèjimas, migravimas iš vieno kontinento į kitą anksčiau buvo retas dalykas, dabar dèl technikos pažangos (lèktuvų, greitujų traukinių) prieinamas daugiau asmenu ir igauna visiškai naujus mastus. Kita vertus, naujosios technologijos, išradimai, idejos, kultūros vertybès ir simboliai nepaprastai greitai plinta po visus žemynus. Technogeninès civilizacijos skleidžiamas visuotinumas ir totalumas apima visas postmodernios metacivilizacinès kultūros ir žmonių gyvenimo sritis skirtinguose kontinentuose ir visose valstybėse.

Daugiakultūriškumas ir jo atsvara tarpkultūriškumas implikuoja daugybę ivairių santykio būdų tarp skirtingų kultūrų individų ir jų grupių. Kultūrų sąveikos vienaip ar kitaip keičia visus ilgainiui suvokiama, kad pokytis, savotiškas tapimas kitais, yra neišvengiamas, o gal ir būtinas susiduriančiu kultūru rezultatas. Kismas yra tolydus, transformacija nepertraukiama. Nè viena kultū$\mathrm{ra}^{1}$ negali išlikti steriliai homogeniška ir nè vienas individas negali išvengti tapsmo esant sąveikai ir komunikacijai. Bū- tent kūrybinis kultūros sąveikos veiksmas - tapsmo kitais kildinimas mikro ir makro lygmenimis - sudaro šio reiškinio tvermès esmę. Prancūzų civilizacijos ir kultūros korifëjus Fernandas Braudelis taikliai pastebejo, kad „iš tikrųu nèra nė vienos šiuolaikinès kultūros, kurią galima būtu tikrai suprasti be ankstesniu jos raidos keliu, buvusiu jos vertybiu, sukauptos patirties pažinimo. Kultūra - tai visuomet praeitis, konkreti gyva praeitis. ${ }^{\prime 2}$

Ligšiolinis ir dabarties pasaulis kupinas tarpkultūrinių ìtampų, dinamikos, dialogų ir konfliktų. Čia nestokojama archajinių reliktu - savo ir svetimo skirties, diskriminacijos ir subordinacijos. Kultūrų sąveika, tranformuodama visus sąveikaujančius, dialektiškai susijusi su visais sociokultūriniais virsmais. Deleuziškasis tapsmas kitu šiuo atveju gali būti talpiai perfrazuotas pagal megasociumo masteli - paveikti bet kokios sąveikos niekada nebebūsime tie patys tiek mes, tiek jie būsime jau kiti.

Kultūru sąveika iš esmès apklausia bet kokị homogeniškumą. Ivvairiakultūrinëje visuomenëje, kur sąveikauja keletas ar keliolika kitokių ir net radikaliai skirtingu kultūrų, susikuria ypatingas tarpkultūrinių sąveikų ir poveikių tinklas. Geografiniai, politiniai, ekonominiai skirtingų kultūrų individų ir ju grupių apribojimai, atskyrimai ilgainiui mąžta, keldami vis naujus sąveikos iššūkius, kurie ypač aktualūs patarujų metų Europai. Iš tiesu šiame plačius mastus igavusioje migracijoje iš Sirijos, Eritrejos, Afganistano, Libijos ir kitų kraštu pabėgèlių nẻra nieko naujo, kas mums būtų nežinoma iš ankstesnès civilizacijos istorijos. 
Daugybę dabartinių civilizacinių iššūkių ir problemų daugiausia suaktualina ne tik nuolatos isiplieskiantys geopolitinių konfliktų židiniai, tačiau ir augantis dabarties reiškinių reflektyvumas, sustiprintas elektroninių mediju vienalaikiška agora. Globalus pasaulio reflektyvumas naująsias dabartinio globalaus pasaulio kultūrų sąveikas iškelia ì dramatini lygmeni, čia ir dabar vykstančių pokyčių sukeliamas visuotinis nerimas ir nesaugumas yra absoliučia dabartimi tapusio pasaulio epistema. Dabarties pasaulio refleksijos gylis yra akimirksnio eksplikacija, jis afektyvus, o istorine atmintis tiesiogiai nebedalyvauja arba yra tąsi ir pragmatiškai eksploatuojama. O juk tapatumas kyla ant slenksčio tarp ištakų ir ateities, jis negali būti paliktas vien natūraliai ịvykių tèkmei, ji būtina intelektualiai suvokti ir pasiekti. Istorinè atmintis ir istorinè sąmonė apdovanota svarbia kultūrine funkcija formuoti tapatuma, teigia Jörnas Rüsenas ${ }^{3}$. Tad kultūrų sąveikos, atsitraukdamos nuo istorinès atminties matmens, pačios tampa permanentiniu naujumu. Naujumo epistema - dabarties pasaulio variklis, lygiavertiškai naudojamas kūrimui ir destrukcijai. Kultūrų sąveika dabarties sociokultūriniuose procesuose, išdidinta iki naujumo, par exellence iškreipia ši reiškini ir daro ji nestabilų bei nevaldomą.

Kultūrų sąveika globalizacijos kontekste ne tik nèra naujas reiškinys, priešingai, tik dabar, sparčiai plètojantis gyventojų judrumui, ji igauna visai kitą masteli, atskleidžia latentiniu pavidalu seniai glūdèjusi potencialą. İ kultūrų sąveikos aspektus, dažnai naujus tik mas- teliu ir intensyvumu, galime žvelgti kaip $\mathfrak{i}$ vis intensyvejjančių viso pasaulio sociokultūrinių ryšių ir sąveikų stiprëjimą. Homogeniško, suvienodinto pasaulio vizija, sieta su globalizacijos procesais dar XX a. pabaigoje, XXI a. pradžioje akivaizdžiai virto nepaneigiamu faktu, jog kultūrų, skirtingo etniškumo susidūrimai / susitikimai ne tik kad nesuniveliuoja, bet, priešingai, siekia išlaikyti ir pabrèžti savo skirtybes. „Kultūra nuolatos kažką periminèja iš savo kaimynų, kartu siekia „interpretuoti skolinius sava maniera", asimiliuoti juos. Iš pirmo žvilgsnio kiekviena kultūra yra panaši i prekių stoti, kuri tik tuo užsiiminèja, kad priima ir išsiunčia įvairius krovinius. Tačiau netgi jei to prašo, civilizacija gali atkakliai atsisakyti vienos ar kitos dovanos iš išorès." ${ }^{4}$

Galima sakyti, tai ir yra kultūrų sąveikos tvermè - sąveikaujančiųjų sandų tapatumo išsaugojimas pačiai sąveikai palaikyti. Ištisas sąveikos niuansų spektras nuo asimiliacijos $l \bar{u} k e s c ̌ i o ~ i k i ~ a t v i r o$ kultūrų konflikto ịvykio parodo, jog atskiri kultūrinio, etninio tapatumo dariniai sąveikos sąlygomis tampa sutelktesni, tvaresni, tvirtesni, ju tapatumas sau tampa reflektyvus ir nukreiptas i veiksmą sociumo erdvèje. Kultūrų ìvairovè globalioje erdveje taip pat sukuria specifines sąlygas kultūrų sąveikai, formuoja jos apibrèžtis, išryškina latentinius bruožus. Būtent dèl to, tarp daugelio kitų aspektų, svarbu atkreipti dèmesi i ši progresyviai kintanti kontekstą analizuojant kultūrų sąveikos esmę.

Šiuolaikinès industrinès liberaliosios demokratijos, atrodytu, turi potencialą absorbuoti tarpkultūrinių sąveikų pro- 
cesus ir jų rezultatus, tačiau dèl globalizacijos veiksnių visuomenès, kuriose vyksta ši sąveika, dar niekada iki šiol nebuvo tokios etniškai ivvairios, daugiakultūrès ir prieštaringos, taip pat šios visuomenès susiduria su ypatingai tankiomis ir itemptomis skirtingų etninių kultūrų sąveikomis, dialektiškomis sampynomis, divergentiškais ir heterogeniškais jų ryšiais. Megasociumas perpildytas kultūrinės izvairovès augimo - ši lygiagretè tiksliai atspindi šiuolaikini politini, ekonominį, sociokultūrini pasaulinio mastelio kontekstą. Arjun Appadurai atkreipè dėmesi, jog globaliame sociume kuriasi savotiški „etnovaizdžiai“" riuos sudaro sąveikaujančių, viena kitą pozityviai priimančių etninių grupių kuriami socialiniai peizažai. Šis procesas pastaruoju metu igauna vis didesni pagreiti, yra itin dinamiškas, nors jam netrūksta stabilumo, kuri susikuria nauji etnosocialiniai dariniai.

Kultūrų sąveikos aktualumą itin išryškina milžiniški heterogeniškos prigimties migracijos poslinkiai, būdingi dabarties megasociumui. Nikos Papastergiadis ši reiškini aprašè kaip „migracijos turbulenciją" Nūdienè populiacijos individų migracija yra įvairialypè, milijonai žmonių gyvena migracijos sąlygomis, nėra įmanoma apibrèžti keletą pagrindinių veiksnių, kodèl ji vyksta, skatina žmones keltis arba i gretimas šalis, arba itin geografiškai nutolusias valstybes. Mèginimas apriboti šio fenomeno prigimti politiniais ir ekonominiais motyvais pernelyg susiaurina jo esmę, kuri veikiau glūdi galimybeje, kurią teikia pats megasociumas, nei atskiru procesu pasekmėse (ekonominiai netolygumai, politiniai neramumai etc.). Be to, migraciją lemia ne tik darbo ar karo motyvai, verta atkreipti dèmesi i specifinę migracijos forma, kada individai palieka savo šalis, ipprastinę aplinka, etnini foną siekdami išsilavinimo tose šalyse, kur jis geresnès kokybės ar prieinamesnis.

Kultūrų sąveika skirtingų migracijos formu nulemtomis sąlygomis taip pat yra kitokia, tačiau etnosocialinė tapatumo membrana išlieka ir palaiko skirtingu tapatybių komunikacija, nesvarbu, pozityvi ar negatyvi ji būtų. Be to, migracijos fluidai savitai aktyvavo nacionalistines nuotaikas ir netgi motyvuotus judejimus ilgą nacionalinio tapatumo istoriją turinčiose valstybėse. Anksčiau integruotos etninès bendruomenès ir daugialypiai naujosios migracijos dariniai taip pat sukuria naujas, sunkiai nuspejjamas sąveikas.

Kultūrinio tapatumo galia XXI a. tampa itin ryški ir vienu stipriausių visus kultūrinius, geopolitinius, ekonominius procesus sąlygojančių veiksnių. Nuo XIX a., kai šis fenomenas pateko i tik ką gimusios sociologijos ir kitų visuomenès mokslų akirati, jo apibrěžtys ir ittaka smarkiai kito. Chimeriškas tarpdiscipliniškumas lygiai kaip ir tariama tvarka atskirų mokslų empirinių faktų perteklių nebegali aprèpti, o juolab suvaldyti reiškinio, kuris tampa beveik ašiniu dabartiniame sociume. Ar liberaliosios demokratijos buvo pasiruošusios tokiam intensyviam tautų maišymuisi - sambūviui be asimiliacijos intencijų? Kultūrų sąveika galbūt taip pat tèra viena iš chimeriškuju sąvoku, kurią šiame straipsnyje ivairiais aspektais mėginame aptarti ir išryškinti, tačiau ją atskleisdami ei- 
name keliu, pabrèžiančiu proceso vienalaikiškuma, o ne retrospekcija, i kurią nukreipti humanitariniai mokslai, beveik atsiduodami Michaelio Foulcault dabarties ontologijos neįmanomybei. Nei statistinès empirikos teorinės imperijos, nei spekuliatyvi retrospekcija negali apimti joykio, būtent kuriuo yra tapusi permanentiška kultūrų sąveika šiuolaikiniame pasaulyje. İvykis yra iššūkis bet kuriems prognozavimo mechanizmams, kaip puikiai parodè naujausi tarpkultūriniu pagrindu steigiamo teroro proveržiai, net jei šios smurtinès sąveikos désningumai išgvildenti Slavojaus Žižeko tekstuose. Kultūrų sąveikos virsmas įvykiu, aktualia beprecedente dabartimi, prieš mūsų akis iškelia naują tarpkultūriškumo paveikslą. Gilles Deleuze'as yra pažymèjęs: „...mažumų integracijos problema nèra išsprendžiama per aksiomas, statutus, autonomijas, nepriklausomybes. Žinoma, jų taktika yra to siekti. Tačiau jei mažumos yra revoliucinès, tai tik todèl, kad jos turi daug stipresnę galią kvestionuoti pasaulinę aksiomatiką."

Skirtumai tarp kultūrų yra vienas esminių dalykų tarpkultūrinès komunikacijos tyrimų srityje. Šie skirtumai paprastai laikomi konfliktų ir įvairių nedermių šaltiniu. Apmąstant ontologinius, epistemologinius ir etinius tarpkultūrinès sąveikos aspektus, atsiveria pastaruoju metu itin perspektyviu laikomas kultūru sąveikos kelias - pamatinis dialogiškumas, reiškiantis daugiau nei pasyviai postuluojamą pliuralizma, reliatyvizmą ar prieštaringos ir pavojingos inercijos igijusi daugiakultūriškumą. Modernios valstybès patiria stiprius kultūrinès integracijos išbandymus mėgindamos su- valdyti didejjančius globalios migracijos srautus ir prieštaringais būdais skylančias tarpkultūrines sąveikas. Tokiomis sąlygomis savo ruožtu nuolat plètojantis mokslinei skirtingų kultūrų sambūvio analizei, pamažu išryškèja sąvokų „,daugiakultūriškumas“ ir "tarpkultūriškumas" skirtis. Daugiakultūriškumas tampa problemiška sąvoka, kadangi jis traktuoja kultūrini skirtumą kaip statišką inertišką turini, tam tikrą simbolinį turta telkianti bendruomeninio priklausymo, vertybių sistemos ir kultūrinių praktikų visetą. Daugiakultūriškumą plèšo dvi pamatinès jègos - asimiliacijos būtinybė ir etninių mažumų visapusiško pripažinimo siekis, suvienodejjimo ir radikalios ginties prieštara. Skirtumas daugiakultūriškume nèra dinamiškas ir produktyvus, jis susiduria su daug neišsprendžiamų problemų, priimdamas kultūrinę ìvairovę kaip apriorinę duotybę. Tarpkultūriškumo sąvokos kontūras apima judria, takia, santykinę, tapsmo prisodrintą kultūrų sąveika, teigiančią potencialų kultūrinio tapatumo hibridiškumą bei, iš esmès, paties tapatumo formavimąsi per santyki su kitybe, Kitu. Skirtumas tarpkultūrinëje sąveikoje sumažina ginties itampą ir labiau akcentuoja gebą pripažinti lygiavertiškumą tų, kurių kitokia egzistencija, kitoks elgesys ir kitokios vertybès, sutariant, jog skirtingos tapatybès yra tolygios. Taigi skirtumas yra dalis kultūros gyvybingumo, kuris savo ruožtu parodo, kokiu mastu kultūra paveikiama aplinkybiu, kuriomis formuojasi, taip pat, kokiu mastu ji tuos skirtumus sujungia. Kultūra yra sritis, kurioje sunkiausia pasiekti susitarimų ir išplètoti konceptualius instrumentus, 
galinčius kurti vieningą bendruomenę, gerbiančią įvairovę ir skirtybes savo viduje, teigia Jean-Fredas Bourquinas ${ }^{8}$.

Kultūrinių mažumų, imigracijos ir augančio bendruomenių mišrumo Europos ir pasaulio miestuose patvirtinimas suteikè kultūrai naujų poteksčių. Antropologiniu požiūriu kultūra ilgą laiką buvo suvokiama kaip tęstinè žmoniu grupių sambūvio būklè, pateikianti save skirtingais raiškos būdais. Sekant nūdienai aktualiu kultūru skirtingumo teigimu, iškyla itin svarbūs lygybès, demokratijos reikalavimai tarpkultūrinèje sąveikoje intensyviai kintančiomis geopolitinėmis ir sociopolitinemis aplinkybèmis. Jean-Fredas Bourquinas kelia klausimus, kaip tokiomis sąlygomis turètu būti traktuojama kultūrinè tapatybè, kaip lygybès reikalavimas turètų būti derinamas su skirtumo pripažinimu. Tautos teigia ir gina savo kultūrini ypatingumą, lemia istorinį bendruomenès formavimąsi ir suteikia sau politinį identitetą. Visus šiuos aspektus jos įtvirtina gindamos savo skirtumą nuo aplinkinio pasaulio ir trindamos skirtybes savo ribu viduje. Todèl netgi šiandien valstybèms yra labai sunku apsieiti su kultūriniais skirtumais ir apriboti juos tik privačia sfera9.

Globalizacijos kontekste kultūra nebẻra tai, ką viena ar kita žmoniu grupè turi tapatumo pavidalu, veikiau tai konkrečiai atpažisstamas būdas atitikti gyvenamos aplinkos sąlygas ir ịkūnyti skirtumą išreiškiantị ir mobilizuojantị žmoniu grupių tapatumus, teigia Arjun Appadurai $^{10}$. Tuo tarpu George'as Yúdice'as teigia esant būtina kultūrą globaliame amžiuje suvokti kaip ištekliu, galimą konceptualizuoti, patirti, eksploatuoti, mobilizuoti socialiniuose ir ekonominiuose procesuose, tarpkultūrinèse sąveikose ${ }^{11}$.

Paprastai pastebimi trys kultūru sąveiku variantai: apsauga / gynimasis, adaptacija ir susiliejimas (konvergencija). Visos trys minètos prieigos implikuoja kultūrinių skirtumu problemiškumo sampratą. Skirtumo problema trukdanti sẻkmingai tarpkultūrinei komunikacijai, o panašumai pageidaujami kaip tarpusavio supratimo tarpkultūriniame lygmenyje palengvinimas, tačiau iš šios pozicijos kyla, jog dominuojanti kultūra siekia primesti savo modelius tiems, kurių atžvilgiu dominuoja, galiausiai implikuodama kolonializmą, imperializmą ir netgi genocidą ${ }^{12}$. Ši prieiga yra statiška ir esencialistinè kultūros atžvilgiu, stokojanti istorinio konteksto ir galios santykių tarp skirtingų kultūrų atstovų analizès. Pavyzdžiui, M. K. Asante'as teigia istorinio kontekstualizavimo būtinybę, leidžiančią geriau suprasti atskirų sąveikaujančių kultūrų vidines sistemas, tapatumus, komunikacijos prakti$\mathrm{ką}^{13}$. J. K. Martinas ir T. K. Nakayama pažymi, jog kultūra nèra tik kintanti ir socialiai konstruojama steigtis, tai grumtyniu vieta, kur susiduria ir yra kuriamos ìvairios komunikacinès reikšmès ${ }^{14}$.

Taigi tarpkultūrinius skirtumus akcentuojant kaip problema, neišvengiamai nueinama Vakaru filosofijai, mokslui ir religijai esminiu - dichotomijos - keliu. Ši epistemologinè tradicija sklidina prieštaravimų ir, nors ji ir leidžia pažinti, apibūdinti, aprašyti skirtingas kultūras, tačiau iš esmès riboja, stereotipizuoja ir supaprastina gyvą tarpkultūrinę raišką. Maža to, ji veda i stingdantị redukcionizma, skirianti Vakarus ir visą kitą pa- 
saulì $^{15}$. Kritinei kultūros prieigai atstovaujantys mokslininkai priešinasi šiam statiškam ir dichotomiškam kultūrinio tapatumo principui. Antai tarpkultūrinès komunikacijos teorijos vienas pradininkų S. Hallas teigia, jog kultūrinis tapatumas yra ideologinis konstruktas, sukurtas ir išdèstytas ypatingame istoriniame, diskursyviame ir kultūriniame kontekste $^{16}$. Mokslininkai pripažista kultūrinio hibridiškumo fenomeną ir teigia, jog kultūriniai tapatumai dažniausiai yra nomadiški, ambivalentiški, rizomiški, pereinami. Istorinis ir sociopolitinis kontekstas aprèpia kultūrini tapatumą ir suteikia artikuliuotą erdvę tarpkultūrinèms sąveikoms.

Dominuojanti vakarietiška epistemologija, kuria inertiškai remiamasi tarpkultūrinių sąveikų tyrimuose, iš tiesų minta dar Apšvietos laikotarpiu susiformavusiu universalizuoto žinojimo principu, virtusiu vienamate kolonialistine reprezentacija, kurios centre esencializuotas modernus vakarietiškas subjektas, intelektualiai hegemonijai pajungęs pažinimą ir veiksmą. Kultūrų ìvairovè, jų sąveikų būdų begalybė subordinuojama visuotinai priimtinam vakarietiškajam pasaulèvaizdžiui. Kultūrų skirtumus akcentuojanti esencialistinè tarpkultūriškumo prieiga teigia tam tikrą kultūros esmę, nekintančią ir statiška, be kurios esą konkreti kultūra nustotų egzistuoti taip pat sau. Priešingą ir gerokai produktyvesni požiūrị akcentuoja dialoginès tarpkultūrinès saveikos teorijos, kurioms atstovauja, pavyzdžiui, R. C. Arnett, C. Graysonas, C. McDowellas ${ }^{17}$. Gana novatoriškoje publikacijoje Kaibin Xu Theorizing Difference in Intercultural Com- munication: A Critical Dialogic Perspective pasitelkia dialogini požiūrio taška, svariai paremtą Martino Buberio, Emanuelio Levinaso, Mikhailo Bachtino filosofija ir komunikacijos teoretikais R. C. Arnett, L. A. Baxteriu, S. Deetzu ${ }^{18}$.

Dialoginès Buberio, Levinaso ir Bakhtino teorijos, kuomet jomis vadovaujamasi tiriant tarpkultūriškumą, teigia pastarajji esant dialogini, palaikanti skirtumus, kitybę ir daugybiškumą. Ši prieiga kritikuoja esencialistinị tarpkultūriškumo supratima, pabrèžia kitybę bei santykio su Kitu pamatiškumą ir produktyvuma, taip pat dialektiškumą ir galios santykių subalansavimą dialogo sąlygomis. Dialoginès tarpkultūrinès sąveikos teorijos atmeta autonomiško, sau pakankamo subjekto sampratą ir savęs suvokimą grindžia santykiu tarp savęs ir Kito. Būtent taip orientuotos tarpkultūrinès sąveikos ir komunikacijos teorijos yra iš esmès pagrịstos kitybės prièmimu, supratimu ir igalinimu. Taip pat jos atmeta iš Apšvietos laikų laikų atėjusio "autonomiško pažistančiojo" pozicija, didžiuosius skirties tarp , aš ir kitas“ naratyvus ir teikia prieigas, rymančias ant lokalaus ir takaus kultūriškumo tapatybès suvokimo.

Tad dialogas yra vienovè ir skirtumas, sujungti dinamišku dialektikos sąnariu, leidžiančiu peržengti atskiros kultūros specifinio patyrimo ribas, diskursa, ideologijas ir kt. "Nuo pirmo žodžio dialoge aš susiduriu su tikrove, kuri egzistuoja nepriklausomai nuo mano minčių"19, - teigia A. Brunner. Dialoginès tarpkultūrinès sąveikos prieiga apima ir etini požiūrí, jog nè viena kultūra nèra vienintelè visai žmonijai - toks absoliu- 
tus universalizmas atmetamas teigiant, jog nei Vakarų, nei Rytų kultūros iš esmès nereprezentuoja visos žmonijos kultūrinès galimybės ${ }^{20}$. Toks tarpkultūrinès sąveikos pamatas palaiko kultūrų daugybiškuma, pliuralizma, skirtumų potencialumą ir produktyvumą.

Tačiau tarpkultūrinè sąveika, net jei ir grindžiama trokštamu dialogu, nèra prognozuojamas, juolab kontroliuojamas reiškinys. Ši unikali sąveika prisodrinta tiek kūrybiškų galimybių, tiek ir konfliktų bei kataklizmų. Tarpkultūrinès sąveikos yra tarsi tektoninių plokščiu sandūros, judinamos ontologinio nerimo. Ir nors globaliame pasaulyje kultūrų sąlygos ir santykiai itin varijuoja, būdamos žmogiškųju resursų tiekèjos, jos paradoksaliai palaiko nepaliaujamai kintančią ir neramią žmogaus būklès, kaip ją ivardija Hanah Ardendt, prigimti: , „̌̌monès, pergyvenę naikinimo stovyklas, koncentracijos ir internavimo stovyklų gyventojai ir netgi palyginti laimingi žmonès be valstybès <...> gali matyti, kad didžiausią pavojų jiems kèlè abstraktus buvimas tik žmogumi ir daugiau niekuo. Kaip tik todèl jie buvo traktuojami kaip laukiniai ir, bijodami, kad gali baigtis tuo, jog bus laikomi gyvuliais, jie atkakliai laikėsi savo tautiškumo, paskutinio savo ankstesnès pilietybės ženklo, vienintelio jiems likusio ir pripažinto saito su žmonija." 21

Taigi kultūrinių, o lygia greta ir pilietinių, tautinių konvencionalumų išsaugojimas yra ypatinga tapatumo gintis, tolydžio stiprèjanti augant tarpkultūrinių sąveikų intensyvumui, nesvarbu, kokius pavidalus, pozityvius ar radikaliai negatyvius, tos sąveikos igytų. Pas- tarojo meto dramos Europoje, jau pradedant $X X$ a. viduriu, aiškiai parodo, jog kultūriniai tapatumai ir jų sąveikavimas lengvai tampa politinio instrumentalizmo, ivvairiausių ideologiju manipuliacijos irankiu, vedančiu iki subordinuoto mažumų statuso, etninio valymo, genocido ir visokeriopo pamatinių žmogaus teisių nepaisymo. Giorgio Agambenas savo ižvalgomis apie „nuogą gyvybę" ir homo sacer yra aiškiai atskleidęs tragiškumą to neapibrèžto ir niekaip nevaldomo tarp sociokultūrinių konvencijų, kuriame pavojingai suspaudžiama elementari žmogiškoji esatis. Agambenas teigia, jog bet kuris žmogus netgi demokratinèse visuomenėse virtualiai yra homo sacer ${ }^{22}$. Jean-Fredas Bourquinas savo knygoje Violence, Conflict and Intercultural Dialogue kelia klausima, ar demokratijos geba suvaldyti nuolat pumpuruojanti fatališku konfliktų būvị, skylantị susiduriant įvairioms kultūroms. Skirtingiausi kultūriniai tapatumai susitikdami netgi visiškai naujose geografinèse ir socialinėse erdvėse (migracijos, karo pabėgèlių atveju) išsaugo savotišką tapatumo ginties potencialą ${ }^{23}$. Galima sakyti, kad pastarieji keli XXI a. dešimtmečiai aiškiai parodè, jog ten, kur yra kultūrinių ir kitų tapatumų skirtumai, jų sąveika išsaugo būdraujančią gynybinę būklę ir nesama jokio tarpkultūrinio konformizmo, tolydžios niveliacijos, apie kurią buvo daug diskutuojama XX-XXI a. sandūroje.

„Konfliktų išvengimo būdai nèra esminiai kultūroms", - teigia Jean-Fredas Bourquinas, ir demokratija kol kas, deja, nepajègi sumažinti visų i̇tampų, ypač ten, kur ìsitraukia tarpkultūrinių skirtumų ir sąveikų elementai. „Tarp demokratinių 
praktikų ir skirtingų kultūrų raiškos demokratiniame pasaulyje yra praraja.“ ${ }^{24}$ Tarpkultūrinis dialogas, anot šio mąstytojo, yra itin sunki užduotis šiuolaikiniam, demokratiją privilegijuojančiam pasauliui. Galima netgi manyti esant tam tikros sąveikos tarp konflikto ir kultūros, nes žmogiškosios būtybės negali išvengti konfliktų tiek, kiek jos egzistuoja ir sąveikauja socialiniuose, ekonominiuose, ideologiniuose kontekstuose.

Todèl viena sudètingiausių problemų šiandieninëje kultūrų sąveikos erdvèje žmogaus teisių legitimumas tarpkultūriniu lygmeniu. Labai ižzvalgiai ir išlaikydamas kuo santūresnę distanciją nuo vakarietiškos pozicijos šią temą aptaria Abdullahi Ahmed An-Na'im įvadiniame savo redaguoto rinkinio Human Rights in Cross-Cultural Perspectives. A Quest form Consensus straipsnyje. Jis pažymi, jog tarpkultūrinès sąveikos prieiga gali būti itin produktyvi šalinant neatitikimo tarp žmogaus teisių teorijos ir praktikos priežastis. Pastaruoju metu tampa neišvengiamai būtina stiprinti ir îtvirtinti žmogaus teisių standartus kuo platesnejje kultūrų ìvairovèje. „Esamos ir numatomos žmogaus teisès negali būti laikomos tikrai universaliomis, kol jos nèra suvoktos ir artikuliuotos kuo didesnèje kultūrinių tradicijų ivvairovèje", - teigia $\mathrm{Ab}$ dullahi Ahmed An-Na'im²5.

Žmogaus teisès, kaip normatyvinè pozicija, yra kur kas ittikinamesnès ir lengviau igyvendinamos, jei jos suvokiamos kaip legitimios įvairiose kultūrinèse tradicijose. Kaip prieštara tam, aišku, pasirodo reliatyvizmo nuostatos, tačiau ju pavoju galima pažaboti konstruktyviai analizuojant ir pripažistant problemas, su kuriomis susiduriama itvirtinant žmogaus teises skirtumų kontekstuose. Kadangi kultūros nepaliaujamai vystosi ir kinta tiek vidujai, tiek sąveikaudamos, tampa imanoma paveikti šios kaitos kryptis per tarpkultūrini dialogą. Kadangi tarpkultūrinè sąveika ir abipusè ittaka yra natūralus ir vis dažnesnis reiškinys, i šiuos sąveikos aktus galima îterpti žmogaus teisių elementus, teigia Abdullahi Ahmed An-Na'im².

Akivaizdu, jog žmogaus teisių šiandieninis aktualumas ir prioritetas daro itaką tarpkultūriniams santykiams. Viena kultūra, paveikdama kita, neišvengiamai patiria pokyčių grižtamąji ryšį; būtent ši aspektą reikia pabrěžti siekiant išvengti žmogaus teisių ittvirtinimo kaip primetimo akto kitybei. Beje, minètoje Abdullahi Ahmed An-Na'im redaguotoje knygoje Rhoda Howard kritiškai pažymi, jog pati žmogaus teisių samprata yra grynai modernus darinys, kyląs ne iš antropologiškai grịsto susitarimo dèl žmogaus vertybių, poreikių ir troškimų, bet iš modernaus mąstymo apie teisinę valstybès struktūrą igijusiose visuomenèse $^{27}$. Iš tiesų teisè negali laisvai, kaip tikètasi Apšvietos proveržiu, performuoti santykių tarp individuc, kadangi ji negali būti pritaikyta kultūriniame vakuume, o tai ypač akivaizdu šiandieniame skirtybėmis kunkuliuojančioje globalioje visuomeneje.

Tarpkultūrinis žmogaus teisių legitimumas įmanomas susitariant dèl reikšmès, apimties ir metodų, kuriais šios teisès būtų igyvendinamos skirtingu kultūrų kontekstuose. Kultūrinių skirtumų galimos implikacijos buvo numatytos jau ankstyviausiu Žmogaus Teisių Deklaracijos kūrimo tarpsniu 1947 m., pabrèžiant, jog jautrumas kultūrinèms 
skirtybėms turètų būti vienas svarbiausių jų igyvendinimo principų. Pastaruoju metu, nors gana abstrakčiai, vis dèlto sutariama, kad nepaisant radikalių kultūrinių skirtumų ir savitų ypatybių, žmonès ir visuomenès sutaria dèl tam tikrų fundamentaliu interesų, dalyku, rūpesčių, savybių ir vertybių, kuriuos galima traktuoti kaip konceptualų ir empirini bendro kultūriškumo pagrindą universalioms žmogaus teisèms įsitvirtinti ir veikti ${ }^{28}$.

Tarpkultūrinių sąveikų neiprastai didelis intesyvumas, jų išplitimas pasauliniu mastu, kaip niekad tankus ju reprezentacijų ir reflektyvumo tinklas rodo, jog kultūrose glūdi ypač galingas skirtumo ir kitybės potencialas, kuriam pasirodyti ir reikštis tarsi buvo laukiama sąlygu; dabarties geopolitiniai poslinkiai tas sąlygas vis labiau atveria. Nors kultūriniai skirtumai yra pašalinti iš politinės sistemos ir nukelti tik i privačią individų gyvenimo sfera, tačiau jie grižta i viešąą erdvę iš visiškai netikètų pusių. Itinklintų elektroninių medijų, virtualių socialinių tinklų teikiamas šių poslinkių reflektyvumas dar labiau didina tarpkultūrinès sąveikos slègị. Greita kartų kaita taip pat rodo, jog integracijos, adaptacijos ir kitų tarpkultūrinės sąveikos prieštaringumą amortizuojančiu procesų galia buvo gerokai pervertinta.

Kultūriniai skirtumai suvokiami skirtinguose lygmenyse, teigia Sławomiras Magala $^{29}$. Juo sudètingesnè tampa mūsų visuomenè ir juo labiau spartejja ir intensyvèja globalus žiniatinklis, juo stipriau kyla reikmė dorotis su kultūriniais skirtumais. Dèl šiuolaikinių technologiju jie sustatomi kaip niekad arti, ir galbūt todèl kaip niekada iki šiol išryškejja jų sa- vitumas, autonomiškumas, tvirtumas. Virtualūs ar didelio sociopolitinio pagreičio priversti kultūrų suartèjimai išryškina kultūrų skirtis ir jose glūdinti savitumo ginties branduolį. Technologiškai ir politiškai spartinama kultūrų sąveika pateikia pasauliui nelauktą rezultatą - kultūrų skirtumai "lètesni“ už sąveikų intensyvinima, jie tarsi amortizuoja trupančius ir nykstančius ankstesnio pasaulèvaizdžio pavidalus. Šiuo aspektu žvelgdami susiduriame su dvilype kaitos perspektyva, kurią itin aiškiai pateikia Samuelis P. Huntingtonas ir George'as Ritzeris. Tarsi du kultūrų skirtumais ir sąveikomis tiršto pasaulio poliai, šių dviejų autorių teorijos kasandriškai skelbia dvi galimybes, kurios formaliai nors ir atrodo priešingos, bet iš esmès pateikia tą pačią tapsmo kitu / kitokiu galimybę, kuri bet kuriuo atveju yra neišvengiama. Tarpkultūrinių sąveikų tinklas linkęs tankèti ir veikiausiai nèra jègos, kuri praplèstų šio tinklo akis. Archetipiškos Huntingtono ir Ritzerio teoriju apibrěžiamos jëgos nurodo kokybinio tapsmo neišvengiamybę nepaisant versijų ivvairovès.

Huntingtonas perspejja, kad kultūros gali susidurti gindamos savo vertybes nuo kitų lygiai stiprių, bet visiškai skirtingu tapatybių ${ }^{30}$, o Ritzeris ìspeja dèl galimo šių vertybių išnykimo apskritai visoms tapatybėms tirpstant globaliame rinkos ir vartojimo persunktame, standartizuotame niekyje. Huntingtonas teigia, kad jokie kompromisai tokiuose tarpkultūriniuose susidūrimuose neįmanomi, o Ritzeris mano, kad viskas tampa pernelyg kompromisiška ir nebelieka kam susidurti: „Tikras racionalus pasirinkimas reikalauja bent keleto tikrų al- 
ternatyvų, o ne begalinio tų pačių ar panašių dalykų kopijavimo. “31

Taigi Ritzeris teigia vykstant „niekio globalizaciją", t. y. visų tarpkultūrinių santykių traktavimą kaip sekuliaria, rinkos stumiamą modernizaciją. Spartus vystymasis ir standartizacija, globalus prekių ir paslaugu mainų tinklas pamažu atima iš individų vadinamąsias couleur locale ir genius loci kokybes, ju pabrèžiamą laiko, vietos ir asmens unikalumo patyrimą pakeisdamas beveidèmis stadartizuotomis modernaus pseudovakarietiško braižo gèrybėmis. Tačiau labiausiai George'as Ritzeris akcentuoja greitèjantị ir intensyvejjantị kultūrinių vertybių kismą. Kitaip nei iki šiol buvo tyliai sutariama daugelyje kultūros teoriju (sociologijoje, socialinėje psichologijoje, kultūrinèje antropologijoje), kultūrų vidiniai ir sąveikų sukelti pokyčiai pastaruoju metu vyksta daug greičiau nei iki XX a. vidurio. Be abejo, lètesniam tuometiniam kultūrų sąveikavimui ir kitimui lemiamą poveiki darè Šaltasis karas ir komunistinio bloko įsitvirtinimas didelèje geopolitinèje teritorijoje. Tačiau pastaruoju metu sunkiai nuspejjami ir dar sunkiau kontroliuojami tarpkultūriniai dinaminiai procesai yra veikiami esminiu permainų tiek technologijose, tiek ekonomikoje ar vis labiau persislenkančiuose politinès galios poliuose.

Todèl Huntingtonas pabrèžia aršų, konfliktišką, netgi dramatišką kultūrų susidūrimo scenarijų, kuriam tapus tikrove, pasaulèvaizdis taip pat turètú negrižžtamai keistis. Skirtingai nuo Ritzerio kultūrinio autentiškumo entropijos, Huntingtono piešiamas apokaliptinis peizažas yra radikalus virsmo kitu atvejis, beje, vykdomas kraštutiniais, t. y. karinės, teroristinès agresijos, būdais. Reikia pažymèti, jog lemtingu, milžiniško masto konfliktu perspektyvos nuolat pasirodydavo įvairių mąstytojų knygose, kartais igaudamos katastrofiškos distopijos pavidalą (Oswald Spengler, Undergang des Abendlandes (1918), Aldous Huxley, Brawe New World (1932), George Orwell, 1984 (1949) ir kt.). Tai, kad Huntigtonas, akcentuodamas tarpkpultūrinès sąveikos dabartiškuma ir joykiškuma, pabrèžia lemtingą islamo kultūros įtaka, pamatinio šios numatomos ir vykstančios kaitos principo nekeičia. Kultūrinè Rytų-Vakarų dichotomija taip pat nèra esminè galios poziciju sąvara. Tiesą sakant, pati globalizacijos idèja buvo stipriai kritikuota istoriku (Fernand Braudel, Immanuel Wallerstein), sociologu (Roland Robertson, Arjun Appadurai, Michael Burawoy), politikos mokslų teoretiku (Held, Castells), filosofuc (Antonio Negri, Edward Said) ir ekonomistų (Gunnar Myrdal, Joseph Stieglitz). Dauguma socialiniams mokslams atstovaujančių mokslininkų sutinka su viena bendra teze, jog globalizacija negali būti sutapatinta su paprastu Vakaru modernizacijos plètimusi, kuris esą paveikia visą pasauli ${ }^{32}$.

Tokios, sakytume, homogeniškos globalizacijos vizija svetima rizomiškai išsisklaidžiusiems kultūrų skirtumams, kurie silpniau ar stipriau susiduria skirtinguose lygmenyse. Robertsono sukurta sąvoka "glokalizacija“ iš esmès yra skirta apibrèžti konkrečios savastingos kultūros padèti esant globaliam spaudimui $^{33}$. Robertsonas pabrèžia, jog ne tik vis dažniau ir nepaliaujamai sąveikauja kultūros, bet taip pat mes vis geriau isisąmoniname itin intensyvejjantį tarpkul- 
tūriškuma, o tai savo ruožtu kuria ne tik kritinius požiūrius, bet ir atveria naujas galimybes dar savitesniems ir sudètingesniems skirtingų kultūrų sąveikavimo būdams ateityje.

Pasaulio kaip nuolatinio tarpkultūrinio sąveikavimo visumos kūrimasis, skirtumų dinamiškas heterogeniškumas savo ruožtu augina šio proceso reflektyvuma, globalią / virtualią sąmonę, nes šiandieninè multimedija leidžia mums nagrinèti savo refleksijas nepaliaujamai visą laiką. Taip besirandanti globalizacijos ir vakarietiškų vertybiu plitimo kritika sukuria naujus galingus vožtuvus, palaikančius kultūru skirtumus.

\section{UŽSKLANDA}

Taigi kultūrų sąveika, nepaisant dabartini pasauli draskančiu geopolitinių, periodiškai įsižiebiančių nauju dramatišku konfliktu, kaip tokia išlieka ivvairiausiose istorinėse, sociopolitinèse ir kitose visuomenès slinktyse, ilgainiui išryškindama savo nelygstamumą, būtinumą apibrèžtí. Kultūru sąveika pastaruoju metu vis labiau tiriama kaip dialogiška ir dialektiška kitybès dinamika, skatinanti vienas kultūras pažinti kitas. Kito samprata tarpkultūrinèse są-

\section{Literatūra ir nuorodos}

1 Sąvoka kultūra čia vartojama plačiausia prasme kaip ,,istoriškai perduodamas simbolių reikšmių derinys, paveldètų sampratų sistema, išreikšta simboline forma tais būdais, kuriais vyrai ir moterys komunikuoja, i̇amžina ir plètoja gyvenimo pažinimą ir pasaulejautą" (Clifford Geertz, Interpretations of Culture. New York: Basic Books, 1973, p. 89).

2 Fernand Braudel, Grammaire des civilisations. Flammarion, Paris, 1993, p. 68.

3 Jörn Rüsen (ed.), Westen Historical Thinking. An Intercultural Debate. New York, Oxford: Berghahn Books, 2002.

4 Fernand Braudel, Grammaire des civilisations. Flammarion, Paris, 1993, p. 73.

5 Arjun Appadurai, Disjuncture and Difference in the Global Cultural Economy. Theory Culture Society 1997, p. 297.

6 Nikos Papastergiadis, The Turbulence of Migra- veikose nebėra statiška ir esencialistiška, veikiau ji nurodo aktyvu, nors ir labai prieštaringa, kitybiškumo, skirtingumo pradą. Skirtumas tampa produktyviu pamatu tiek kūrybiškai tarpkultūrinių sąveikų sklaidai, tiek šių sąveikų keliamų problemų supratimui ir malšinimui. Tarpkultūrinėse sąveikose išryškejjanti skirtumo būtinybè yra pozityvi, nes išlaiko pliuralistišką tapatumų tinklą. Skirtumas tampa kultūru sąveikos modus operandi.

tion: Globalization, Deterritorialization and Hybridity. Oxford: Polity Press, 2000.

7 Gilles Deleuze, The Logic of Sense. Trans. Paul Patton. London, New York: Continuum, 2004, p. 521. (cituojama iš: Audronè Žukauskaitè, Nuo biopolitikos iki biofilosofijos. Vilnius: Kitos knygos, 2016, p. 84).

8 Jean-Fred Bourquin, Violence, Conflict and Intercultural Dialogue. Strasbourg: Council of Europe Publishing, 2003, September, p. 29.

9 Jean-Fred Bourquin, Violence, Conflict and Intercultural Dialogue. Strasbourg: Council of Europe Publishing, 2003, September, p. 30.

10 Arjun Appadurai, Modernity at Large: Cultural Dimensions of Globalization. Minneapolis: University of Minnesota Press, 1996.

11 George Yúdice, The Expediency of Culture: Uses of Culture in the Global Era. Durham, NC: Duke University Press, 2003. 
12 Kaibin $\mathrm{Xu}$, Theorizing Difference in Intercultural Communication: A Critical Dialogic Perspective, Communication Monographs, Vol. 80, No. 3, September 2013, p. 381.

${ }^{13}$ M. K. Asante, Intercultural Communication: An Inquiry into Research Direction. Communication Yearbook 4, 1980, p. 401-410.

14 J. K. Martin ir T. K. Nakayama, Thinking dialectically about Culture and Communicaton. Communication Theory 9, 1999, 1-25.

${ }^{15}$ Kaibin $\mathrm{Xu}$, Theorizing Difference in Intercultural Communication: A Critical Dialogic Perspective, Communication Monographs, Vol. 80, No. 3, September 2013, p. 381.

16 S. Hall, Cultural Identity and Diaspora. J. Rutherford (Ed.), Identity: Community, Culture and Differences, 1990. London: Lawrence \& Wshart, p. 222-237.

17 R. C. Arnett, C. Grayson, C. McDowell, Dialogue as an "enlarged communicative mentality": Review, assessment, and ongoing difference. Communication Research Trends 27, 2008, p. 3-25.

18 Kaibin $\mathrm{Xu}$, Theorizing Difference in Intercultural Communication: A Critical Dialogic Perspective. Communication Monographs. Vol. 80, No. 3, September 2013, p. 379-397.

19 A. Brunner, La connaissance humaine, cituojama iš Dictionaire de la langue philosophique. PUF, Paris, 1962, p. 26.

${ }^{20}$ Kaibin $\mathrm{Xu}$, Theorizing Difference in Intercultural Communication: A Critical Dialogic Perspective $(\mathrm{Xu}, 390)$.
${ }^{21}$ Hannah Arendt, Totalitarizmo ištakos. Verte Arvydas Šliogeris. Vilnius: Tyto alba, 2001, p. 299.

22 Giorgio Agamben, Homo Sacer: Sovereign Power and Bare Life. Trans. Daniel Heller-Roazen. Stanford: Stanford Univerity Press, 1998.

${ }^{23}$ Jean-Fred Bourquin, Violence, Conflict and Intercultural Dialogue. Strasbourg: Council of Europe Publishing, September, 2003, p. 30.

24 Ten pat, p. 10.

25 Abdullahi Ahmed An-Na'im (Ed.), Human Rights in Cross-Cultural Perspectives. A Quest form Consensus. Philadelphia: University of Pennsylvania Press, 1992, p. 2.

26 Ten pat, p. 4.

27 Rhoda E. Howard, Dignity, Community, and Human Rights. Abdullahi Ahmed An-Na'im (Ed.), Human Rights in Cross-Cultural Perspectives. A Quest form Consensus. Philadelphia: University of Pennsylvania Press, 1992, p. 65-81.

28 Abdullahi Ahmed An-Na'im (Ed.). Human Rights in Cross-Cultural Perspectives, p. 21.

29 Sławomir Magala, Cross-Cultural Competence. London, New York: Routledge, 2005, p. 48.

30 Samuel P. Huntington, Political Order in Changing Societies. Yale University Press, 2006.

31 George Ritzer, The McDonaldization of Society. London: SAGE Publications, 2004, p. 215.

32 Sławomir Magala, Cross-Cultural Competence. London, New York: Routledge, 2005, p. 59.

33 Roland Robertson, Glocalization: Time-Space and Homogeneity-Heterogeneity. Global Modernities. Ed. M. Featherstone, S. Lash, R. Robertson. London: SAGE, 1995. 